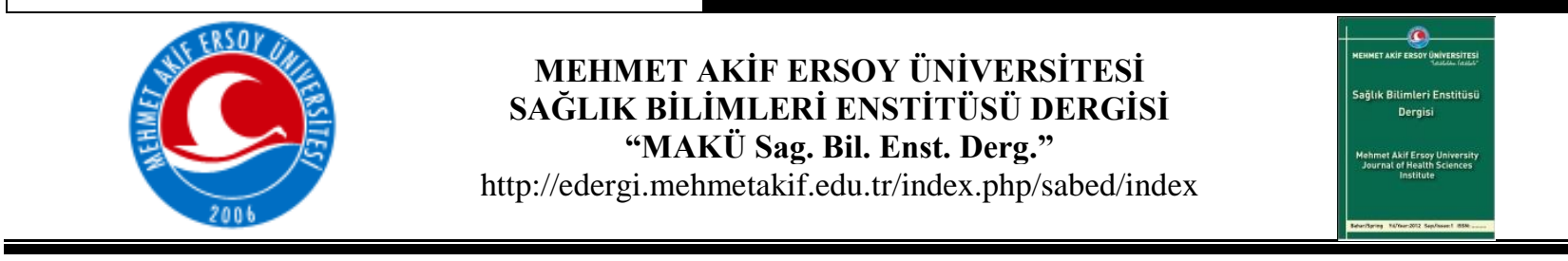

\title{
Kanatlı ve Memeli Karaciğerinde Karbonhidrat ve Yăg Metabolizmasının Karşılaştırılması
}

\author{
Comparison of Carbohydrate and Fat Metabolism in Poultry and Mammalian \\ Liver
}

\author{
Füsun Erhan ${ }^{1}$, Levent Ergün ${ }^{1}$ \\ ${ }^{1}$ Ankara Üniversitesi, Veteriner Fakültesi, Histoloji ve Embriyoloji Anabilim Dalı, ANKARA, TÜRKIYE
}

\begin{abstract}
Liver is a complex organ located under the diaphragm in the right upper of abdomen together with gallbladder and bile duct and is essential for life. Liver delivers the absorbed nutrition from digestive system for utilization of other body compartments or passes them to the bloodstream after processing. Therefore, it creates a transition zone between digestive tract and blood. Blood carrying the nutrition from digestive tract is transmitted to hepatocytes through sinusoid walls after carried to sinusoids. Products obtained from hepatocyte processing are sent to duodenum as exocrine secretion (bile) via bile ducts or back to sinusoids again as endocrine secretion (proteins, lipids..) and from there they are sent to associated body parts by bloodstream. Liver has important functions in carbohydrate and lipid metabolism. Though poultry and mammalians share similarity of carbohydrate and fat metabolism, there are differences in metabolism pathways, hormonal response, enzyme regulation and factors effecting metabolism. For example, poultry have higher fasting blood sugar levels than mammalians due to their weak insulin sensitivity. Important differences of enzyme activities in carbohydrate and lipid metabolism occur in incubation period of chicks and in transition period from fetal to neonatal life of mammalians. Besides, mammalians need maternal energy sources in order to develop in intrauterine life and to meet metabolic demands. Since poultry develop independently from their mother, no maternal support is needed. This circumstance leads to arise of metabolic differences between poultry and mammalians before they connect with the external world.
\end{abstract}

Key words: Liver, carbohydrate metabolism, lipid metabolism.

Yazışma Adresi: Prof. Dr. Levent ERGÜN Ankara Üniversitesi, Veteriner Fakültesi, Histoloji ve Embriyoloji AD, 06110, Dışkapi/ANKARA.

E-posta: lergun06@hotmail.com

Tel: +90 5333168491

Kaynak göstermek için: Erhan F, Ergün L. 2018. Kanatlı ve Memeli Karaciğerinde Karbonhidrat ve Yağ Metabolizmasının Karşılaştırılması. MAKÜ Sag. Bil. Enst. Derg. 6(1): 33-42. doi: 10.24998/maeusabed.356417
Öz: Yaşam için temel organlardan biri olan karaciğer, safra kesesi ve safra kanalı ile birlikte diyaframın altında bulunan ve karın boşluğunun sağ üst köşesine yerleşmiş olan kompleks bir organdır. Karaciğer, sindirim kanalından emilen besinleri işleyerek vücudun diğer doku ve organlarının yararlanması için depolar ya da kan dolaşımına verir. Bu nedenle sindirim sistemi ile kan arasında bir geçiş bölgesi oluşturur. Sindirim sistemi organlarından gelen besinleri içeren kan, karaciğer sinuzoidlerine taşındıktan sonra sinuzoidlerin duvarından hepatositlere aktarılırlar. Hepatositlerde işlenerek elde edilen ürünler; ya dış salgı olarak (safra) safra kanalları aracılığıyla duodenum'a gönderilir, ya da iç salgı olarak (çeşitli proteinler, lipidler ) tekrar sinuzoidlere aktarılırlar ve oradan kan dolaşımı ile ilgili yerlere dağıtılırlar. Karaciğer, karbonhidrat ve lipid metabolizmasında önemli birçok fonksiyonu gerçekleştirir. Kanatlilar ve memeliler arasında karbonhidrat ve yağ metabolizmaları bazı yönleriyle benzerlik gösterse de metabolizma yolakları, hormonal cevap, enzim regülasyonu ve metabolizmayı etkileyen faktörler açısından birtakım farklılıklar bulunmaktadır. Örneğin; kanatlılarda insüline karşı duyarlılığın zayıf olmasından dolayı, normal açlık kan şekeri düzeyi memelilerden daha yüksektir. Karbonhidrat ve lipid metabolizmasına katılan enzimlerin aktivitelerindeki önemli değişiklikler civcivlerin kuluçka döneminde, memelilerin ise fötal dönemden neonatal döneme geçiș aşamasında gerçekleşir. Ayrıca memelilerde intrauterin hayatta fötusun gelişebilmesi ve metabolik ihtiyaçlarını karşılayabilmesi için maternal enerji kaynaklarına ihtiyaç vardır. Kanatlılarda gelişim, anneden bağımsız izole bir ortamda gerçekleştiği için maternal bir destek söz konusu değildir. Bu durum kanatlı ve memeliler arasındaki metabolizma farklılıklarının, henüz dış dünya ile bağlantı kurulmadan ortaya çıkmasına neden olmaktadır.

Anahtar sözcükler: Karaciğer, karbonhidrat metabolizmas1, yağ metabolizmas1.

Geliş Tarihi: 20.11.2017～Kabul Tarihi: 24.04.2018 


\section{Giriş}

Karaciğer, sindirim kanalından emilen besinleri işleyerek diğer vücut kısımlarının yararlanması için depolayan ya da kan dolaşımına veren kompleks bir organdır. Bu nedenle sindirim sistemi ile kan arasında bir geçiş bölgesi oluşturur. İnce bağırsaklardan emilen maddelerin çoğu portal ven yoluyla karaciğere ulaşırken, sadece lipidler (şilomikronlar) lenf damarlarıyla taşınırlar. Sindirim sistemi organlarından gelen besinleri içeren kan vena porta yolu ile karaciğer sinuzoidlerine taşındıktan sonra, sinuzoidlerin duvarından komşuları olan hepatositlere aktarılırlar. Hepatositlerde işlenerek elde edilen ürünler ya dış salgı olarak (safra) safra kanalları aracılığıyla duodenum'a gönderilir, ya da iç salgı olarak (çeşitli proteinler, lipidler) tekrar sinuzoidlere aktarılırlar ve oradan kan dolaşımı ile ilgili yerlere dağıtılırlar (Junqueira ve Charneiro, 2009).

Karaciğer, karbonhidrat ve lipid metabolizmasında önemli birçok fonksiyonu gerçekleştirir. Karaciğerde bulunan tüm hücrelerin yaklaş1k \%80'ini oluşturan hepatositler ise bu fonksiyonları gerçekleştiren önemli hücrelerdir (Mitra ve Metcalf, 2009). Tek bir hepatosit 500'den daha fazla özel metabolik aktiviteyi aynı anda gerçekleştirebilmektedir (Solomon ve ark., 1999). Bu kadar yoğun aktiviteye sahip hepatositler, organelden zengindir (Sağlam ve ark., 2001). Özellikle granülsüz ve granüllü endoplazmik retikulum bakımından zengin olan hepatositlerde bu organellerin miktarları hücrenin metabolik aktivitelerine bağlı olarak değişebilir. Sitoplazma içinde genellikle dağınık olarak bulunan granülsüz endoplazmik retikulum, hücrenin yapacağı işlevlere göre granüllü endoplazmik retikulum ile Golgi aygıtı arasında da sıklıkla gözlenir. Her karaciğer hücresinde sitoplazma içinde çok sayıda mitokondriyon bulunur. Bu mitokondriyonlar, metabolik olaylar için gerekli enerjinin (ATP) üretimine yönelik enzimler içerirler. Hepatosit sitoplazmasında lipid metabolizması için gerekli olan enzimleri taşıyan peroksizomlar da bulunmaktadır (Kannenberg ve ark., 1999; Van Den Bosch ve ark., 1992).

$\mathrm{Bu}$ derlemede, karaciğerde karbonhidrat ve lipid metabolizmasının memeliler ile kanatlılar arasındaki farklılıkları anlatılmıştır.

\section{Metabolizma}

Metabolizma, alınan besin maddelerinin sindirilmesi, emilmesi, kan ve lenf yolu ile çeşitli organ, doku ve hücrelere taşınması, hücrelerde kullanılması gibi olayların tümünü içermektedir (Sözbilir ve Bayşu, 2008). Kanatlı ve memelilerde hem metabolik süreçlerde hem de metabolizmayı etkileyen faktörler açısından çeşitli farklılıklar vardır. Örneğin; 
kuluçka sıcaklığı, tavuk embriyo gelişimini ve kuluçka süresini etkileyen önemli fiziksel faktörlerden birisidir. (Decuypere ve Michels, 1992). Genellikle yüksek sicaklığın kanatlılarda embriyonik gelişimi hızlandırdığı ve kuluçka süresinin kısalmasına neden olduğu bilinmektedir. Düşük sıcaklık ise tam tersi etki göstermektedir (Black ve Burggren, 2004; Kaplan ve ark., 1978). Memelilerde sıcaklığın metabolizma üzerindeki etkisi, glukoz ve lipid homeostazisinde ortaya çıkar. Buna en iyi örnek yüksek sıcaklıkta ineklerin adipoz doku rezervlerini kullanmak yerine glukozu enerji kaynağı olarak tercih etmeleridir. Yüksek sıcaklık memeli hayvanlarda hormonal değişikliklere sebep olarak karaciğer fonksiyonlarını etkileyebilir (Sucu ve ark., 2015).

Kuluçka döneminde yumurta kabuğu içerisinde gelişen embriyo hızla büyür ve kütlesi yüz kata kadar artabilir. Embriyonun büyümesindeki artış metabolizma hızını önemli derecede artırır (Vleck ve ark., 1980). Aynı şekilde memelilerin de gebelik döneminde, oksijen tüketiminin artmasına bağlı olarak metabolizma hızında da artış olur (Taşkın 2003).

\section{Karaciğerde karbonhidrat metabolizması}

Vücut, enerji ihtiyacının \%55'ini karbonhidratlardan sağlar. Besinlerdeki karbonhidratlar; monosakkaritler (fruktoz, pentoz), disakkaritler (sukroz, laktoz) ve polisakkaritlerdir (nişasta, glikojen). Kan şekeri olarak da bilinen glukoz, canlıların en önemli yakıtıdır. Kan glukoz düzeyini düşürücü ve yükseltici yönde etkili olan olaylar karbonhidrat metabolizmasını oluşturur (Altınışık, 2010). Karbonhidrat metabolizmasında yıkım olayı gastrointestinal sistemde gıdaların sindirilmesi ile başlar ve karbonhidrat bileşiklerinin enterositler tarafindan monosakkarit şeklinde absorpsiyonu ile devam eder. Monosakkaritler açlık halinde kullanılmak üzere, pentoz fosfat yolu, sitrik asit döngüsü ve glikolizis yolu ile aerobik ve anaerobik solunum için hücrelere transfer edilir. Hücrelerin glukoz gereksinimi olmadığında ise monosakkaritler, iskelet kası hücreleri ve karaciğer epitel hücrelerinin granülsüz endoplazmik retikulumunda glikojen formunda depo edilirler (Dashty, 2013).

Vena porta yolu ile karaciğere taşınan (Rui, 2014) glukoz, polar bir molekül olduğundan hücre membranından geçebilmek için transport proteinine ihtiyaç duyar (Gürdol, 2013). Memelilerde ve kanatlilarda kan glukozu, hepatosit plazma membranında bulunan ve glukoz transportunda rol alan GLUT2 (internal proteinler) proteini aracılığı ile hücre içine taşınır (Seyer ve ark., 2013). Hepatositlerde hücre içi glukoz konsantrasyonu, glukokinaz enziminin glukozu glukoz-6-fosfata dönüştürmesi ile azalmaya başlar. Böylece glukoz, hepatositlerdeki taşıyıcı proteinler ile taşınamayacak formda (G6P şeklinde) hücre içerisinde 
kalır (Rui, 2014). Glukojenezis adı verilen glikojen sentezi ile hepatositlerin granülsüz endoplazmik retikulumunda glukoz-6-fosfat, glikojene dönüştürüldükten sonra sitoplazmada depo edilir. Depo glikojen histolojik olarak Periyodik asit Schiff (PAS) reaksiyonu ve Best carmin boyamalarıyla demonstre edilebilirler. Depo glikojen, granülsüz endoplazmik retikulum keseciklerine yakın bir konumda bulunur. Granülsüz endoplazmik retikulumun glikojen metabolizmasıyla ilgili işlevi glikojenin parçalanması ve glukozun hepatositlerden salınması sırasında da ortaya çıkmaktadır. Zira glukoz-6-fosfataz enzimi, granülsüz endoplazmik retikulum membranlarında bulunmaktadır (Rosen ve ark., 1966). Glikojen içeren hepatosit elektron mikroskopla incelendiğinde, sitosolde kümeler halinde ve granülsüz endoplazmik retikulumun yakınında granüller halinde bulunduğu görülür (Gartner ve Hiatt, 2006; Junqueira ve Charneiro, 2009). Hepatosit sitoplazmasında glikojenik bölgelerde peroksizomlara da rastlanır (Parkes ve ark., 1990; Cardell ve Cardell, 1990). Kan glukoz düzeyi normalin altına düştügünde glikojen tekrar granülsüz endoplazmik retikulum tarafından glukoza dönüştürülerek kana verilir ve enerji gereksinimleri için kullanılır (Reece, 2004).

Karbonhidrat olmayan bileşiklerden (glikojenik aminoasitler, laktat, propiyonat, gliserol gibi) glukoz sentezlenmesi olarak tanımlanan glukoneojenez, diyetle sağlanan karbonhidratların yetersiz olduğu durumlarda vücudun glukoz ihtiyacını karşılar. Karaciğer glikojen rezervinin tükendiği açlık durumunda glikoneojenez oldukça önemlidir. (Reece, 2004). Lipidlerin ve aminoasitlerin glukoneojenez adı verilen karmaşı bir enzimatik olayla glukoza dönüştürülmesi hepatositlerde granülsüz ve granüllü endoplazmik retikulum işbirliği ile gerçekleşmektedir (Babcock ve Cardell, 1974; Babcock ve Cardell, 1975).

Karaciğerde glikojen miktarı hormonal mekanizmalar ile düzenlenir. Kan glukoz düzeyinin kontrolü, insülin ve glukagonun antagonist çalışması ve adrenalin, tiroksin (T4), somatostatin, nöronostatin hormonları ile sağlanır (Reece, 2004; Samson ve ark., 2008).

\section{Kanatlı ve memelilerde karbonhidrat metabolizmast}

Memelilerde fötustaki metabolizma ve büyüme için gerekli olan besini plasenta ve fötal karaciğer sağlar (Battaglia ve Meschia, 1978). Çoğunlukla karbonhidratlar, glukoz ve laktat şeklinde fötusa verilir fakat fötusun esas enerji kaynağı glukozdur ve bunu plasenta yoluyla anneden alır (Solomon ve ark., 1999). Bu nedenle memeli fötusunda glikojenez çok sınırlıdır (Ballard ve Oliver, 1963, Ballard ve Oliver, 1965). Glukoz, kolaylaştırılmış difüzyon ile enerji kullanılmadan plasentadan geçer. Fötal glukoz konsantrasyonu maternal glukoz 
konsantrasyonunun \% 70-80'i kadardır (Bell ve ark., 1993). Gebelikte hepatik glukoz üretimi, fötusun artan ihtiyaçlarını karşılayacak şekilde düzenlenmiştir (Battaglia ve Meschia, 1978). Gebeliğin başlangıcında bazal glukoz ve tokluk insülin konsantrasyonları, gebelik öncesi dönemden farklı değildir. Gebeliğin ilerlemesi ile birlikte bazal ve tokluk insulin konsantrasyonlarında kademeli bir şekilde artış gözlenir (Solomon ve ark., 1999). Glikojenez olayı yeni doğan dönemde artış gösterir ve doğumdan kısa süre sonra maksimum seviyelere ulaşır (Ballard ve Oliver, 1963, Ballard ve Oliver, 1965).

Fötus enerji kaynakları olarak laktat, keto asitler, amino asitler, yăg asitleri ve glikojen gibi diğer substratları da kullanabilir (Blackburn, 2003). Normalde fötusda hepatik glukoneojenez (Kalhan ve Parimi, 2000) sadece maternal açlik durumunda görülür (Rao ve ark., 2013). Glukoneojenik sistemin fötal karaciğerde zayıf olmasının veya olmamasının nedeni muhtemelen, memeli fetüsunun maternal dolaşımdan sürekli bir glukoz desteği almasındandır. Yeni doğan dönemde ise tiroit, kortizol ve katekolaminlerin etkisiyle hepatik glikoneojenez olayı başlar (Kalhan ve Parimi, 2000). Doğumla birlikte yavru anneden yüksek yağl1, düşük karbonhidratlı sütle beslendiği için yeni doğan döneminde glukoz, glikoneojenez yoluyla oluşturulur (Ballard ve Oliver, 1965).

Kanatlılarda embriyo, maternal kaynaktan sürekli bir glukoz kaynağı olmaksızın izole edilmiş bir sistem içinde gelişir ve bu nedenle embriyonik gelişim boyunca aktif bir glukoneojenez gerçekleşir. Kanatlılılarda embriyo karaciğerinde çok az miktarda karbonhidrat depolandığı için kan glukoz konsantrasyonunun korunması glukoneojeneze bağlıdır. Glikoneojenez enzimleri civciv embriyo gelişimi ilerledikçe artar ve kuluçka süresi boyunca maksimuma ulaşır. Kuluçka döneminden sonra yüksek karbonhidratlı diyetlerle beslendiklerinden zayıf glukoneojenez gözlenir (Krishan ve ark., 1971).

Kanatlıların 21 günlük kuluçka döneminin son 7 gününde ana besin kaynağını yumurta sarısı oluşturmaktadır. $\mathrm{Bu}$ yumurta sarısında bulunan düşük miktarlardaki karbonhidratlar, embriyonik gelişim süreci için gerekli enerjiyi sağlamaktadır (Freeman ve Vince, 1974). Glikojen, embriyo karaciğerinde inkübasyonun 6. gününde görülür ve inkübasyonun 19. gününde maksimum konsantrasyona ulaşır. $\mathrm{Bu}$ süre zarfında glikojen metabolizması enzimlerinin aktivitelerinde de paralel bir artış görülür (Ballard ve Oliver, 1963). Uni ve ark. (2012) tarafindan; kanatlılarda sarı kesesinin, glukozu sentezleyen ana organ olabileceğini ve 19 günlük embriyo karaciğerinden 20 kat daha fazla glikojeni depolayabileceğini öne sürülmüştür. Kuluçkadan çıkmaya doğru sarı kesesi, karaciğere kıyasla embriyoya 10 kat daha fazla glukoz aktarma potansiyeline sahip olabilir. Bu nedenle, 
yumurta sarıs1, glukozun sentezi ve depolanmasında önemli bir rol oynar ve kanatlı embriyosuna yumurtadan çıkana kadar destek olur. Embriyonik gelişimin son haftasında yumurta sarısı, kuluçka öncesi günlerde embriyoya verilmesi için karbonhidrat depolayan önemli bir glikoneojenik ve glikojenik ekstraembriyonik organdır. Laktat ve gliserol, glukoneojenik kaynak maddelerdir (Uni ve ark., 2012).

Erişkin memelilerde glikoneogenezisin \%90 kadarı karaciğerde, \%10 kadarı da böbreklerde gerçekleşir. Civciv embriyosunda böbrekte glukoneogenezis gerçekleşmez. Gerek kümes hayvanları gerekse diğer kanatlılar, açlıkta kan glukoz düzeyini korurlar. Kanatlıların açlık kan şekeri düzeyi memelilerdekinden daha yüksek, hepatik glikojen düzeyi ise daha düşüktür (Sözbilir ve Bayşu, 2008). Kanatlı türlerindeki kan glukoz konsantrasyonu düzeyi memelilerde hiperglisemiyi düşündürecek kadar yüksektir (Hazelwood, 1986). Kanatlılardaki bu durumun nedeni insüline karşı duyarlılığın düşük olmasından kaynaklanabileceği öne sürülmektedir (Buyse ve ark., 2009).

\section{Karaciğerde yă̆ metabolizması}

Karbonhidratlar ve proteinlerle birlikte organizmanın temel organik maddelerini oluşturan lipidlerin hücre zarlarında yer almak gibi bazı yapısal fonksiyonları yanında, asıl görevleri organizmanın karbonhidratlardan sonra en önemli enerji kaynağı olmalarıdır. Besin maddelerinin büyük bir kısmı önemli oranda lipid içerir. Diyetteki lipidlerin büyük çoğunluğunu trigliseritler, az bir kısmını fosfolipitler, kolesterol ve kolesterol esterleri oluştururlar (Ası, 1999).

Karaciğer, lipid metabolizmasında merkezi bir role sahiptir. Bundan dolayı tüm lipid gruplarındaki maddeleri yapısında taşır. Dokusundaki lipid oranı çeşitli etkenlere bağlı olarak değişmekle birlikte ortalama \%5 düzeyindedir. Hepatositler plazmadan aldığ1 serbest yağ asitlerini trigliserit ve fosfolipid sentezinde kullanır. Kolesterol sentezi ve plazma kolesterol düzeyinin denetimi de karaciğerin görevlerindendir (As1, 1999).

Trigliseridler, fosfolipidler, kolesterol ve kolesterol esterleri ağızda ve midede değişikliğe uğramadan ince bağırsaklarda hidrolitik olarak parçalanırlar (Ası, 1999). İnce bağırsaklarda yağların enzimatik sindirimi üzerine etkili maddeler, karaciğerin safra salgısı ve pankreasın ekzokrin bölümünden salgılanan lipazdır. Safra, bikarbonat içeriği sayesinde yağların sindiriminden sorumlu enzim olan lipazı aktive eder. Safra ve lipaz aktivitesi altında trigliseritler, monogliseritlere ve yağ asitlerine ayrılır. Bu maddeler safra asitleri ile birleştiklerinde küçük miseller şekillenir. Misel oluşumları, enterositlerin fırçamsı kenarına 
ulaştıklarında monogliseritler ve serbest yağ asitleri difüzyon yoluyla enterosit içine girerler. Enterositlerin endoplazma retikulumunda tekrar birleşerek trigliseritleri oluştururlar. Trigliseritler, golgi kompleksinde kolesterol ve fosfolipidlerle birleşerek şilomikron adı verilen polarize globüller oluştururlar. Golgi kompleksinden ayrılan şilomikronlar, eksositoz ile salgılanır ve lenf dolaşımına ulaşırlar. Lenf sistemindeki şilomikronlar, duktus torasikus vasıtasıyla sistemik dolaşıma katılırlar. Buradan karaciğer ve diğer dokular vasıtasıyla hızla alınarak depo edilirler veya katabolizmaya uğrarlar. Memelilerde yağların emilimi, villuslardaki lenf damarları vasıtasıyla olur. Kuşlarda ise yağların emilimi villusardaki kan damarları yoluyla olur (Reece, 2004). Emilim olaylarını takiben kana geçen serbest yăg asitleri karaciğer tarafından tutularak çok düşük dansiteli lipoprotein (VLDL-şilomikron) formuna dönüştürülür ve tekrar kana geri verilir (Kutlu ve ark., 2005). Şilomikronlar girdikleri dokularda parçalanarak yine yapı taşlarına ayrılırlar. Böylece açı̆̆a çıkan yă̆ asitleri ve diğer lipidler, parçalandıkları dokulara göre değişik biçimlerde kullanılırlar (Ası, 1999).

Mikroskobik incelemelerde karaciğer epitel hücresinde trigliseritler sitoplazmada yer alırlar (Ası, 1999). Hepatositteki farklı boyutlarda yăg damlacıkları uygun tespitlerden sonra Sudan, Toluidine Mavisi veya Oil-Red O boyaması ile gösterilebilirler. Normalde karaciğerde bulunan lipidler, küçük damlacıklar halinde görülür. Lipid metabolizmasının düzenlenmesinde insulin, adrenokortikotropik hormon (ACTH), adrenalin, tiroid ve ghrelin hormonlarının önemli rolü vardır (Sözbilir ve Bayşu, 2008; Buyse ve ark., 2009).

\section{Kanatlı ve memelilerde yăg metabolizması}

Memelilerde fötal lipidler gebeliğin başlangıç döneminde maternal serbest yağ asitlerinden türetilir (Rao ve ark., 2013). Plasentadan fötusa gliserol ve bazı serbest yağ asitleri geçebilirken trigliseritler geçemezler (Herrera ve Amusquivar, 2000; Rao ve ark., 2013). Fötal dokuda lipid sentezi olayı gebeliğin ilerleyen dönemlerinde gerçekleşir. Fötustaki aktif lipogenezis ve gebeliğin ilerleyen dönemlerinde maternal beslenmedeki artış, 1sı ve enerjinin korunmasında önemli olan esmer yağların gelişimini artırır. Doğumdan sonraki dönemde sütteki yüksek lipid içeriğinden dolayı yavruda lipogenezis azalır. Düşük yoğunluklu lipoprotein gebeliğin ilerleyen dönemlerinde en yüksek düzeyine ulaşmasına karşın, doğumdan hemen önce azalır. Maternal lipid metabolizması, erken gebelikte maternal yağ depolarını artırırken ileri gebelikte lipolizi artırarak glukoz ve amino asitlerin fötüs için kullanımını sağlar ve maternal enerji kaynağı olarak yă̆ asitlerinin kullanımını destekler. 
Maternal enerji metabolizması, fötal enerji metabolizmasını kısa ve uzun dönemde etkiler (Rao ve ark., 2013). Embriyonal dönemde yavru metabolik yolla glukoz sentezleyemez. Bu nedenle yavru, doğumdan sonraki ilk günlerde bir miktar glukoz depo etmek zorundadır. $\mathrm{Bu}$ durum fötusun plasenta aracılığı ile maternal enerji kaynaklarını kullanmasına neden olur (Ağaoğlu ve Akgül, 2006). Gebelik süresince metabolik açıdan farklılaşmış iki dönem vardır. Bunlardan ilki, gebeliğin ilk üçte ikisi boyunca fötusun gelişiminin sınırlı olması nedeniyle annenin yeme isteğinin arttığı ve buna bağlı olarak aldığı gıdaların fazlasının yağ olarak depolandığı dönemdir. İkincisi ise, gebeliğin son üçte birinde fötal büyümenin çok hızlı olduğu ve bu hızlı büyümenin ihtiyaçlarını karşılamak üzere ilk dönem depo yağları ile birlikte plasenta yoluyla besin maddelerinin transferinin arttı̆̆ı dönemdir (Martin ve ark., 1994). Gebeliğin ilerleyen dönemlerinde ortaya çıkan bu yıkım evresi maternal insülin direncinin ortaya çıkması ile açıklanabilir. $\mathrm{Bu}$ insülin direnci, insülin karşıtı hormonlarının salgılanmasında artışa sebep olur. Artan insülin direnci ile birlikte maternal glukoz kullanımı da azalır (Knopp ve ark., 1973).

Memeliler gibi kanatlılar da enerji kaynağı olarak lipidleri kullanırlar. Lipidler, karbonhidrat ya da protein ile karşılaştırıldığında yüksek enerji değerine ve düşük su içeriğine sahiptirler. Kanatlılarda bulunan yağ asitleri ve gliseridlerin büyük çoğunluğu diyetle alınan karbonhidratlardan elde edilir. Kanatlılarda lipid metabolizması memelilerden farklıdır, çünkü lipidlerin çoğu doğrudan çok düşük yoğunluklu lipoproteinler olarak portal sisteme geçerler. Memelilerde, öncelikle şilomikron olarak lenf dolaşımına geçtikten sonra kan dolaşımına geçiş yaparlar. Şilomikronlar, kanatlı plazmasında nispeten düşük konsantrasyonlarda bulunur. Kanatlılarda yağ asidi sentezi, yağ dokuda oldukça azdır fakat karaciğerde aktiftir. Yapılan in vivo çalışmalarda civcivlerde yăg asidi sentezinin yaklaşık \%70' inin karaciğerde meydana geldiği gösterilmiş ve kanatlı yağ dokusunda, ratlarda olduğu gibi lipid sentezinden ziyade lipid depolandığı ileri sürülmüştür (Krishan ve ark., 1971).

Kanatlılarda kuluçkadan çıkışı takip eden ilk hafta boyunca hızlı bir şekilde artan ve üçüncü haftadan erginliğe ulaşıncaya kadar yavaş yavaş azalan lipogenezis erginlikten sonra minimal seviyede seyreder (Krishan ve ark., 1971). Gelişen kanatlı embriyosunun başlica enerji kaynağını yumurta sarısında \%50 oranında bulunan lipidler oluşturur. Yumurta sarısında bulunan proteinler de, inkübasyonun ortalarından itibaren gelişmekte olan embriyo için bir enerji kaynağı olarak kullanılır. Kuluçka döneminin son haftası boyunca ise yăg asitlerinin $\beta$ oksidasyonu, embriyo için ana enerji kaynağı haline gelir. Embriyo için tek lipid kaynağı da (yağ asidi oksidasyonu ile) yumurta sarısıdır. Sarı kesesinden lipidlerin alınması 
ilk iki hafta boyunca oldukça yavaştır fakat kuluçka döneminin son haftasında hızlanır. Kuluçka döneminin son haftasında yumurta sarısındaki lipidlerin emiliminin artmasına bağlı olarak embriyonun karaciğerinde lipid konsantrasyonu sekiz kata kadar artarken kuluçkadan çıktıktan sonra büyük bir miktarı hala emilmemiş olarak kalır. Embriyo, kuluçkadan çıkma süreci için ve daha sonra kullanmak üzere enerji kaynağı olarak belirli miktarda yağı absorbe etmek zorundadır. Kuluçka döneminin son haftasında düşük miktarda yağ alımı kuluçkadan çıkış süreci için zararlı etkilere neden olabilir. Kuluçkadan çıkmak için gerekli olan yüksek enerji ihtiyacı ve nispeten düşük oksijen bulunması nedeniyle yağ asitleri, embriyo için inkübasyonun son 2. ve 3. günü gerekli enerjiyi sağlayamayabilir. Bu nedenle embriyo karaciğer, böbrekler ve kasların glikojen rezervlerinde tutulan glukoza ve glikoneojenez tarafından üretilen glukoza doğru yönlendirilir (Uni ve ark., 2012). İnkübasyon döneminin sonuna doğru yumurta sarısı abdominal boşluğa doğru çekilir. Kuluçkadan çıkışı takiben yumurta sarısı ya direkt olarak kan dolaşımına ya da ince bağırsağa transfer olmak suretiyle, kuluçkadan sonraki dönemde civcivlerin hem beslenmesi hem de ince bağırsağın gelişimi için kullanilır (Sklan, 2001).

\section{Sonuç}

Kanatlılar ve memeliler arasında karbonhidrat ve yağ metabolizmaları bazı yönleriyle benzerlik gösterse de metabolizma yolakları, hormonal cevap ve enzim regülasyonlarında birtakım farklılıklar bulunmaktadır. Memeli embriyosunun aksine kanatlılarda karaciğerin erken farklılaşmasına (embriyonik dönemin 4. günü) bağlı olarak, kanatlı embriyosunda gelişimin erken evrelerinde metabolik aktivasyonun başladığı düşünülmektedir (Hamilton ve ark., 1983; Wolf ve Luepke, 1997). Ayrıca memelilerde intrauterin hayatta fötusun gelişebilmesi ve metabolik ihtiyaçlarını karşılayabilmesi için maternal enerji kaynaklarına ihtiyaç vardır. Kanatlılarda gelişim, anneden bağımsız izole bir ortamda gerçekleştiği için maternal bir destek söz konusu değildir. Bu durum kanatlı ve memeliler arasındaki metabolizma farklılıklarının, henüz dış dünya ile bağlantı kurulmadan ortaya çıkmasına neden olmaktadır. 


\section{Kaynaklar}

1. Ağaoğlu ZT, Akgül Y. 2006. Koyunların ketozisi. "Geviş Getiren Hayvanların İç Hastalıkları". Malatya: Medipres.

2. Altınışık M. 2010. Karbonhidrat Metabolizması Bozukluklarına Biyokimyasal Yaklaşım. ADÜ Tıp Fakültesi Dergisi. 11, 51 - 59.

3. Ası T. 1999. Tablolarla Biyokimya Cilt 2. Erişim:

[http://80.251.40.59/veterinary.ankara.edu.tr/fid anci/Ders_Notlari/Tablolarla_Biyokimya/TBLipid_Metabolizmasi.pdf] Erişim Tarihi: 17 Aralık 2016.

4. Babcock MB, Cardell RR. 1974. Hepatic glycogen patterns in fasted and fed rats. Am. J. Anat. 140, 299-338.

5. Babcock MB, Cardell RR. 1975. Fine structure of hepatocytes from fasted and fed rats. Am. J. Anat. 143, 399-438.

6. Ballard FJ, Oliver IT. 1965. Carbohydrate Metabolism in Liver from Foetal and Neonatal Sheep. Biochem. J. 95, 191.

7. Ballard FJ, Oliver IT. 1963. Glycogen metabolism in embryonic chick and neonatal rat liver. Biochimica et Biophysica Acta. 71, 578588.

8. Battaglia FC, Meschia G. 1978. Principal substrates of fetal metabolism. Physiol Rev. 58, 499-527.

9. Bell GI, Burant CF, Takeda J, ve ark. 1993. Structure and function of mammalian facilitative sugar transporters. J Biol Chem. 268, 19161-4

10. Black JL, Burggren WW. 2004. Acclimation to hypothermic incubation in developing chicken embryos (Gallus domesticus): I. Developmental effects and chronic and acute metabolic adjustments. The Journal of Experimental Biology. 207, 1553-1561.

11. Blackburn ST. 2003. Maternal, fetal, and neonatal physiology. Saunders, an imprint of Elsevier Inc.

12. Buyse J, Janssen S, Geelissen S, ve ark. 2009. Ghrelin modulates fatty acid synthase and related transcription factor mRNA levels in a tissue-specific manner in neonatal broiler chicks. Peptides. 30(7), 1342-1347.

13. Cardell RR, Cardell EL. 1990. Heterogeneity of glycogen distribution in hepatocytes. J. Electr. Micro. Tech. 14(2), 126-139.

14. Dashty M. 2013. A quick look at biochemistry: Carbohydrate metabolism. Clinical Biochemistry. 46, 1339-1352.

15. Decuypere E, Michels H. 1992. Incubation temperature as a management tool: A review. World's Poult. Sci. J. 48(1), 28-38.

16. Freeman BM, Vince MA. 1974. Development of the Avian Embryo. London: Chapman and Hall.

17. Gartner LP, Hiatt JL. 2006. Color Textbook of Histology. 3th ed. Elsevier.

18. Gürdol F. 2013. Bilimin Mum Işı̆̆ında Yemek “ Beslenmenin Biyokimyası". Nobel Tıp Kitabevleri.

19. Hamilton JW, Denison, MS, Bloom SE. 1983. Development of basal and induced aryl hidrocarbon (benzo[ $\alpha]$ pyrene) hydroxylase activity in the chicken embryo in ovo. Proc. Natl. Acad. Sci USA. 80(11): 3372-3376.

20. Hazelwood RL. 1986. Carbohydrate Metabolism. In: Avian Physiology. SpringerVerlag New York, 303-325.

21. Herrera E, Amusquivar E. 2000. Lipid metabolism in the fetüs and the newborn. Diabetes Metab Res Rev.16, 202-10.

22. Junqueira LC, Charneiro J. 2009. Temel Histoloji text\&atlas. İstanbul: Nobel Tip Kitabevleri.

23. Kalhan S, Parımı P (2000). Gluconeogeneis in the fetus and neonate. Semin Perinatol. 24(2), 94-106.

24. Kannenberg F, Ellinghaus P, Assmann G, ve ark. 1999. Aberrant oxidation of the cholesterol side chain in bile acid synthesis of sterol carrier protein-2/sterol carrier protein-x knockout mice. J. Biol. Chem. 274(50), 35455-60. 
25. Kaplan S, Kolesari GL, Bahr JP. 1978. Temperature Dynamics of the fertile chicken egg. Am. J. Physiol. 234(5), 183-187.

26. Knopp RH, Saudek CD, Arky RA, ve ark. 1973. Two phases of adipose tissue metabolism in pregnancy: maternal adaptations for fetal growth. Endocrinology. 92(4), 984-988.

27. Krishan L, Rahej A, James G, ve ark. 1971. Activities of some enzymes involved in lipogenesis, gluconeogenesis, glycolysis, and glycogen metabolism in chicks (Gallus Domesticus) from day of hatch to adulthood. Comp. Biochem. Physiol. 39, 237-246.

28. Kutlu HR, Görgülü M, Çelik LB. 2005. Genel Hayvan Besleme Ders Notu. [http://traglor.cu.edu.tr/objects/objectFile/Wcx 8NSgF-2232013-5.pdf] Erişim Tarihi:14 Ocak 2017.

29. Martin HA, Holm C, Belfrage P, ve ark. 1994. Lipoprotein lipase and hormone-sensitive lipase activity and mRNA in rat adipose tissue during pregnancy. Am. J. Physiol. 266, 930935 .

30. Mitra V, Metcalf J. 2009. Metabolic functions of the liver. Anaesthesia and Intensive Care Medicine. 10(7), 13:2.

31. Parkes JL, Cardell EL, Grieninger G, ve ark. 1990. Glycogen metabolism in cultured chick hepatocytes: a morphological study. Anatom. Rec. 227(3),321-333.

32. Rao PN, Shashidhar A, Ashok C. 2013. In utero fuel homeostasis: Lessons for a clinician. Indian $\mathrm{J}$ Endocrinol Metab. 17(1):60-8.

33. Reece WO. 2004. Dukes Veteriner Fizyoloji. Medipres Matbaacılık Yayıncılı, pp. 383527.

34. Rosen SI, Kelly GW, Peters VB 1966. Glucose-6-phosphatase in tubular endoplasmic reticulum of hepatocytes. Science. 152, 352354.

35. Rui L. 2014. Energy Metabolism in the Liver. Compr Physiol. 4(1), 177-197.
36. Sağlam M, Aştı RN, Özer A (2001). Genel Histoloji. Ankara: Yorum Matbaacılık.

37. Samson WK, Zhang JV, Avsian-Kretchmer O, ve ark. 2008. Neuronostatin encoded by the somatostatin gene regulates neuronal, cardiovascular, and metabolic functions. The Journal of Biological Chemistry. 283, 31943195.

38. Seyer $\mathrm{P}$, Vallois D, Poitry-Yamate $\mathrm{C}$, ve ark. 2013. Hepatic glucose sensing is required to preserve beta cell glucose competence. J Clin Invest. 123, 1662-1676.

39. Sklan D. 2001. Development of the digestive tract of poultry. World' s Poultry Science Journal, 57, 415-428.

40. Solomon EP, Berg LR, Martın DW. 1999. Biology. Saunders College Publishing.

41. Sözbilir NB, Bayşu N. 2008. Biyokimya. Güneş Tip Kitabevleri, 101-500.

42. Sucu E, Akbay KC, Filya İ. 2015. Ruminantlarda Sicaklı Stresinin Metabolizma Üzerine Etkileri. Atatürk Üniversitesi Vet. Bil. Derg. 10(2), 130-138.

43. Taşkın L. 2003. Kadın Sağlığı ve Hastalıkları Hemşireliği. Ankara: Akademisyen Kitabevi.

44. Uni Z, Yadgary L, Yair R. 2012. Nutritional limitations during poultry embryonic development. J Appl Poult Res. 21 (1): 175184.

45. Van Den Bosch H, Schutgens RB, Wanders RJ, ve ark. 1992. Biochemistry of peroxisomes. Annu. Rev. Biochem. 61,15797.

46. Vleck CM, Vleck D, Hoyt DF. 1980. Patterns of metabolism and growth in avian embryos. Amer. Zool. 20, 405-416.

47. Wolf T, Luepke NP. 1997. Formation of micronuclei in incubated hen's eggs as a measure of genotoxicity. Mutat. Res.-Gen. Tox. En. 394: 163-175. 